\title{
Using Fly Ash And Bottom Ash Boiler Of Palm Oil Factories As Adsorbents For Adsorption Of Color In Artificial Liquid Waste
}

\author{
Juang Jaya Putra Telaumbanua \\ Department Of Environmental Engineering, University Of North Sumatra, Jl. Dr. Mansur No. 9 Padang Bulan, \\ Kec. Medan Baru, Kota Medan 20222
}

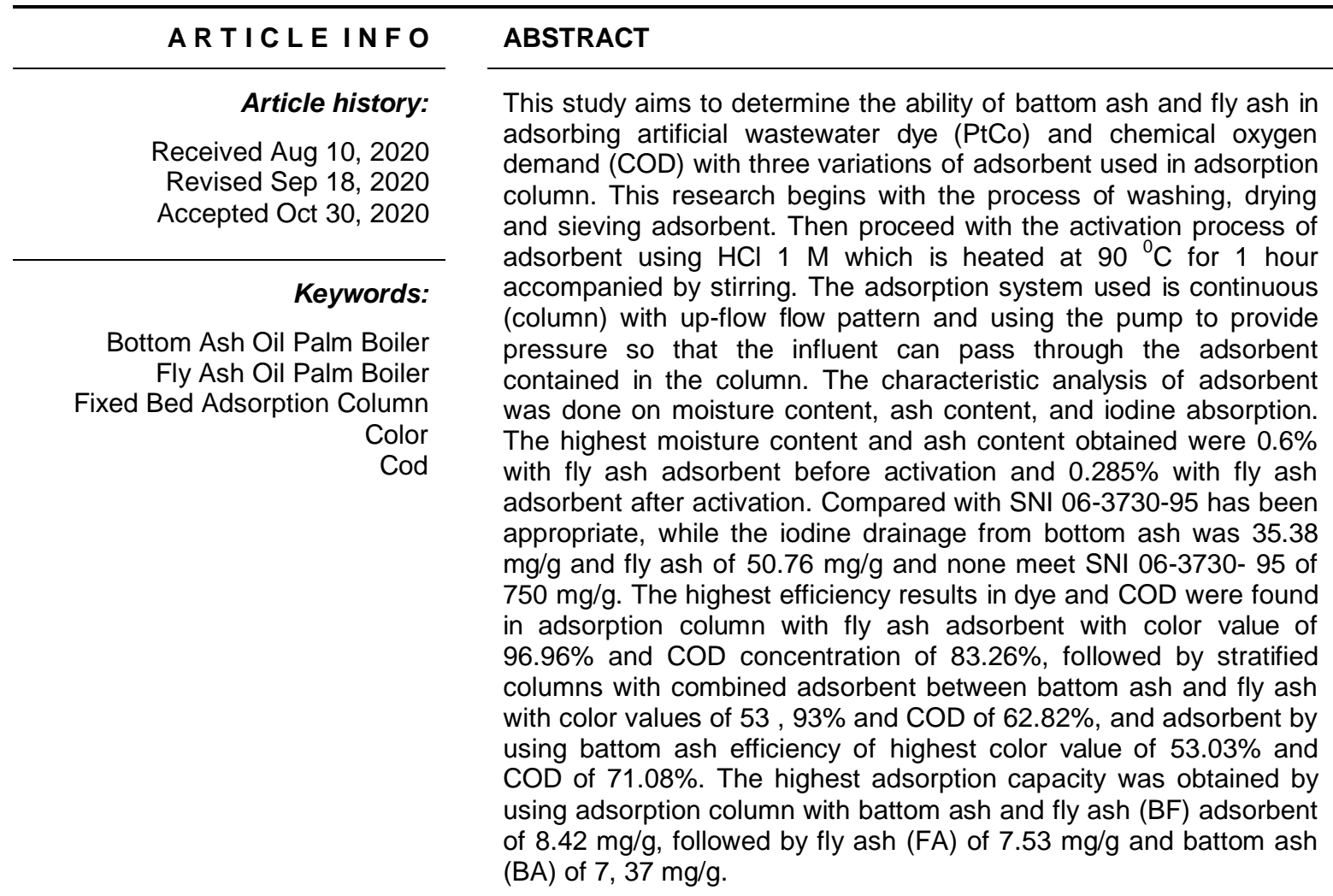

This is an open access article under the CC BY-NC license.

\section{Corresponding Author:}

Juang Jaya Putra Telaumbanua,

Department Of Environmental Engineering,

University Of North Sumatra,

Jl. Dr. Mansur No. 9 Padang Bulan, Kec. Medan Baru, Kota Medan 20222.

Email : jayaputra@gmail.com

\section{INTRODUCTION}

Palm oil in Indonesia is a vegetable commodity as a producer of Crude Palm Oil (CPO) with an area of $4,763,797$ hectares of oil palm with production 11,267,161 tons based on Indonesia's plantation statistics in 2016. With such a large area of oil palm cultivation, oil palm plantations and their processing plants have the potential to produce $\mathrm{CPO}$ and besides that, they also produce a 
very large amount of organic waste compared to other plantation crop wastes. These abundant natural resources are scattered in various parts of Indonesia, especially in Sumatra and Kalimantan.

The development of the palm oil industry that continues to increase will have an impact on solid waste generated from processing fresh fruit bunches (FFB). F, Irene. (2010) said that solid waste in the form of palm kernel shells and fibers has been used as fuel in palm oil mills since the factory was established to produce electricity and water vapor used for processing in the factory. Shell burning, as well as FFB, produce waste in the form of ash which is not utilized and managed properly so that it can cause environmental damage. The combustion ash from the boiler is called Palm Oil Fuel Ash (POFA) (Farandia., 2015).

Liquid waste comes from factories which usually use a lot of water in the production process. Water from factories carries a number of solids and particles, both dissolved and settled. Some of these materials are rough and some are smooth. Often the factory effluent is cloudy and has a high temperature. Polluted wastewater has visually identifiable characteristics from turbidity, color, taste, odor, and other indications (Muthawali, 2013).

Color in water is due to the characteristics of the substances present in the water and not to the water molecules themselves, from metals in rocks and soil, from soil organic matter and plants. Colors in water and wastewater are divided into two, namely true colors and false colors. True color comes from dissolved organic substances, minerals, chemicals in water that cannot be separated by filtration, water color is caused by heavy metals, generally because iron, copper or manganese, leaves and peat can add tannins, glucose, and others, which can produce yellow or brown zones. While the pseudo color comes from suspensions and colloidal materials that can be separated by filtration, and comes from industrial waste which usually produces various chemicals and colors.

From the description above, it can be concluded that the ash from palm oil mills can be used as an adsorbent to adsorb dissolved and insoluble substances in wastewater. In addition, palm ash is easy to obtain, available in large enough quantities and cheap so that it is very effective to use as an adsorbent. In this study, boiler ash was used to adsorb dyes in artificial liquid waste. Boiler ash used in this study is bottom ash and fly ash which have been activated with $1 \mathrm{M} \mathrm{HCl}$ solution and use a column system with an up flow pattern. because in the column system, the solution is always in contact with the adsorbent so that the adsorbent can adsorb optimally until the saturation condition is when the effluent concentration approaches the influent concentration.

\section{RESEARCH METHOD}

\subsection{Research Flowchart}

The research to be carried out is an experimental research with a laboratory scale. This study was conducted to determine the ability of BA and FA from palm oil mills as adsorbents that have been activated using $1 \mathrm{M} \mathrm{HCL}$ to absorb artificial liquid waste using the up-flow column method.

\subsection{How Adsorbent Preparation and Activation Works Adsorbent Preparation}

The adsorbent preparation process begins with washing the BA and FA of the palm oil mill using water to remove impurities and separate the shells contained in the ash and after that the ash is dried in an oven until the ash is dry. Furthermore, BA and FA were sieved to obtain 140 mesh or $105 \mathrm{~m}$.

\subsection{Adsorbent Activation Process}

Before the activation process is carried out, the BA and FA boilers are first washed with distilled water, then dried in an oven at $1100 \mathrm{C}$ for 3 hours, after which the ash is weighed dry. Furthermore, the $\mathrm{BA}$ and $\mathrm{FA}$ boilers were activated with $1 \mathrm{M} \mathrm{HCl}$ solution accompanied by heating at $90 \mathrm{OC}$ for 1 hour. The activation process is carried out by comparing $\mathrm{BA}$ and $\mathrm{FA}$ with $\mathrm{HCl}$, which is 1:4. After that, the BA and FA boilers were drained from the HCL solution and washed again with distilled water until the $\mathrm{pH}$ of the ash became neutral. The BA and FA boilers were then re-dried in the oven at $1100 \mathrm{C}$ for 3 hours.

\subsection{Sampling Method}


The adsorbent samples in the form of BA and FA were taken before and after the activation process and then stored in a closed container for testing the characteristics of BA and FA with water content, ash content, and iodine absorption. The next sample, namely effluent from the adsorption process with BA and FA, was collected in a closed container which was taken every 16 minutes, then tested for COD concentration and color. This was done for the effluent in the adsorption process of column I, column II and in the adsorption process carried out with a stratified system, namely column III.

\subsection{Data analysis}

Data analysis was carried out on the characteristics of the adsorbent originating from the bottom ash boiler and fly ash of the palm oil mill. The data analysis was carried out on each adsorbent with the same activation process. Data analysis was also carried out on dyes using the color value measurement method (PtCo), COD removal efficiency, breakthrough curve for color and $\mathrm{COD}$ values, and COD adsorption capacity obtained by numerical integral equations based on Simpson's method.

\section{RESULTS AND DISCUSSIONS}

\subsection{Preparation and Activation of Bottom Ash and Fly Ash Boiler Boiler Adsorbents for Palm Oil Mills}

This study used bottom ash (BA) and fly ash (FA) adsorbents sourced from two PKS. Fly ash was obtained from PTPN III Sei Mangkei and bottom ash was obtained from PTPN III Sei Silau. Both of these ashes were chemically activated using $1 \mathrm{M} \mathrm{HCl}$ to remove impurities or by-products that covered the ash pores. Activation is carried out to increase the adsorption ability to absorb dyes and Chemical Oxygen Demand (COD) contained in artificial tea wastewater. The size of BA and FA used in this study was 105 m or passed on a 140 mesh sieve which can be seen in Figure 1.

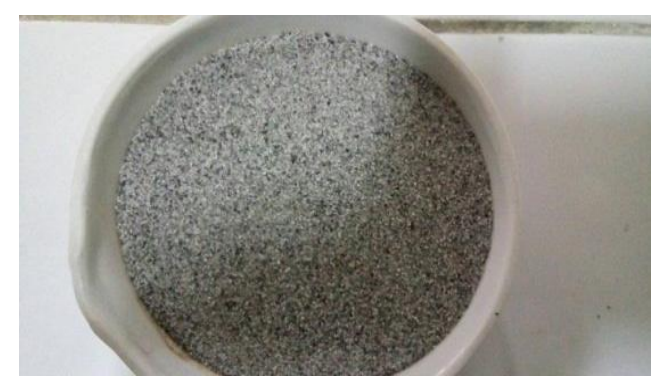

Figure 1. Fly Ash Activated with $1 \mathrm{M} \mathrm{HCl}$

In Figure 1, the color of BA is darker than FA, it is because the ash source comes from a different factory and BA has relatively a lot of impurities mixed under the furnace. The combustion temperature of $\mathrm{BA}$ is between $700-800 \mathrm{OC}$, while FA has a combustion temperature of 800-1000 0C and $F A$ is finer in color with a grayish white color.

\subsection{Characteristics of Bottom Ash and Fly Ash}

\section{a. Water content}

The water content test aims to determine the hygroscopic nature of the ash. Water content testing was carried out on bottom ash and fly ash before and after activation. BA and FA ash was heated at $110 \mathrm{OC}$ for 3 hours to evaporate the water still contained in the ash which can be seen in Figure 2. 


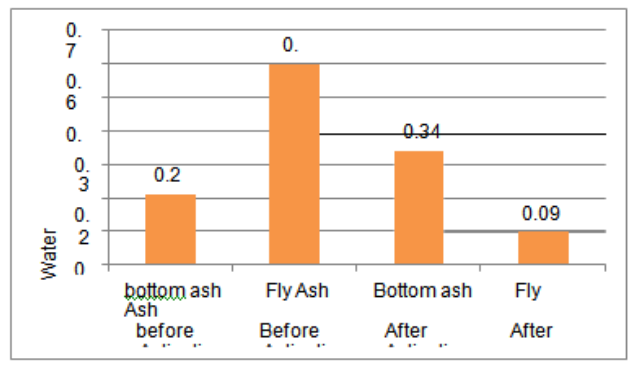

Figure 2. Water Content of Bottom Ash and Fly Ash Before and After Activation

Based on the water content of BA and FA, coconut mills are relatively low because high water content will affect the absorption of liquid. Low water content is expected to have good absorption because the pores are not closed by water so that it has a large absorption. The data in Figure 4.2 shows that the highest water content value is fly ash before activation of $0.6 \%$ and followed by bottom ash after and before activation and fly ash after activation. The high water content in fly ash before activation was due to the ash storage not being carried out in a closed manner so that the water around the ash absorbed into the ash as it is known that the preparation of BA and FA ash from sieving and storage was carried out in an open state.

When compared with activated charcoal-based adsorbents, the water content is influenced by hygroscopic properties, the amount of water in the air, the length of the cooling, milling and sieving processes. High water content can reduce the adsorption power of activated charcoal to liquids and gases (Wibowo, et al. 2009).

According to Mu'jizah (2010), the lower the water content, the more space in the pores that can be occupied by the adsorbate so that the adsorption takes place optimally. The binding of water molecules on the adsorbent by the activator causes the pores in the carbon ash to get bigger. The larger the pores, the larger the surface area of the adsorbent. This results in an increase in the adsorption ability of the adsorbent.

\section{b. Ash Level}

Ash content testing aims to determine the content of metal oxides and minerals in BA and FA ash which is not wasted during combustion and activation. Ash content testing is carried out on BA and $\mathrm{FA}$ before activation and after activation with $1 \mathrm{M} \mathrm{HCl}$.

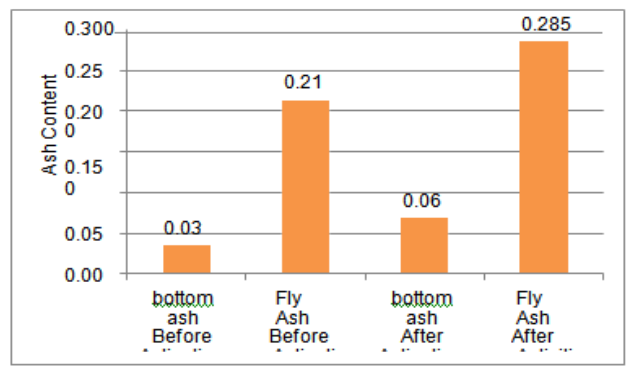

Figure 3. Ash Content of Bottom Ash and Fly Ash

The results of the ash content test showed that the ash content of BA was smaller than that of FA both before activation and after activation in a furnace at $600 \mathrm{OC}$ for 4 hours. The high ash content after activation is because the activator reacts with the metals that cover the surface of the adsorbent to form salts that can dissolve into the activator solution so that when heated at a temperature of $6000 \mathrm{C}$, the salts also burn.

According to Budiono (2006) the high and low ash content is influenced by the activator in dissolving inorganic minerals contained in activated charcoal. The ash formed is because the material has mineral elements such as calcium, potassium, sodium, and magnesium. The content 
spreads in the activated charcoal lattice so that it covers the activated charcoal pores (Pari et al., 2001).

According to Herlandien (2013), the remaining minerals will cause blockage of the activated charcoal pores so that it affects the adsorption that occurs.

\section{c. lodine Adsorption}

Lodine absorption aims to determine the ability of the adsorbent to adsorb adsorbates with small molecular sizes ranging from 10 Angstroms. The level of absorption of the adsorbent on iodine can be seen from the number of iodine obtained. The iodine number indicates the amount of iodine $(\mathrm{mg})$ that can be absorbed by one gram of the adsorbent. lodine adsorption is an important parameter to determine the quality of the adsorbent, related to its use in the process of purification, cleaning and blanching and other uses. Determination of iodine absorption was carried out on BA and FA which had been activated with $1 \mathrm{M} \mathrm{HCl}$.

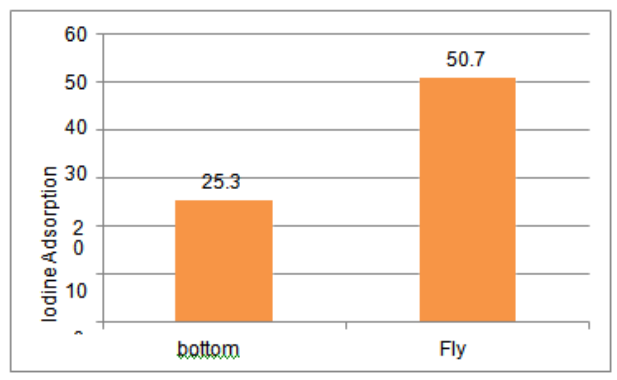

Figure 4. Lodine Adsorption of Bottom Ash and Fly Ash

Based on SNI 06-3730-95 for activated carbon-based adsorbents, the minimum iodine adsorption capacity is $750 \mathrm{mg} / \mathrm{g}$, thus BA and FA adsorbents that have been activated with $1 \mathrm{M}$ $\mathrm{HCl}$ do not meet the requirements because their absorption capacity is below $750 \mathrm{mg} / \mathrm{g}$. This is due to the presence of impurities that cover the pores of the BA and FA ash and the ash has not enough micropores to adsorb the iodine solution. In Figure 4.3 there is a difference in the value of the iodine adsorption capacity of BA and FA, this difference is influenced by the temperature and length of combustion time in the palm oil mill boiler, so it greatly affects the quality of the ash in removing impurities and the formation of ash pores. Different ash collection sites also affect the size of the particles used as adsorbents because BA has a relatively larger size while FA has a relatively smaller size than BA. According to Idrus, R. (2013) The greater the value of the iodine number, the greater the adsorption power of the adsorbent.

\subsection{Adsorption Process in Column Fixed Bed Adsorbers}

The tea solution is passed on the adsorption column in an up flow manner, the adsorbent will bind the dye and COD contained in the solution, then the solution is passed continuously through the adsorbent which is initially free of adsorbate. The bottom of the bed that first received the solution would be very effective at absorbing the dye and COD and the dye and COD that escaped would be absorbed by the next bed. Sampling of the adsorption column effluent was carried out every 16 minutes after the adsorption process took place until it approached the adsorption column effluent concentration with the adsorption column effluent concentration $(\mathrm{Ce} / \mathrm{CO})$ approaching 1 (saturated).

From Figure 4, the fluctuation of COD removal efficiency indicates the occurrence of a deasorption process due to the pressure generated in the up-flow flow of the adsorption column. Due to the flow pressure, the adsorbate that has been absorbed by the adsorbent can be released again. Based on the measurement of the color and COD values of each adsorption column effluent, a breakthrough curve was obtained for each adsorption column which can be seen in Table 1.

Table 1. Comparison of $\mathrm{Ce} / \mathrm{CO}$ Color Value and $\mathrm{Ce} / \mathrm{CO} \mathrm{COD}$ in Each Adsorption Column

Effluent Adsorptio Color Value ( $\mathrm{Pt} \mathrm{Co}$ COD concentration ( $\mathrm{mg} / \mathrm{L})$




\begin{tabular}{|c|c|c|c|c|c|c|c|c|}
\hline adsorbent & $\begin{array}{l}\text { Intake } \\
\text { Time }\end{array}$ & $\begin{array}{c}\text { Contact } \\
\text { Time } \\
\text { (Minute) }\end{array}$ & Influent & effluent & $\begin{array}{l}\mathrm{Ce} / \\
\mathrm{Co}\end{array}$ & Influent & effluent & $\mathrm{Ce} / \mathrm{Co}$ \\
\hline & $\mathrm{t} 1$ & 32 & & 775 & $\begin{array}{c}0.47 \\
0\end{array}$ & & 133 & 0.289 \\
\hline \multirow[t]{6}{*}{$\begin{array}{c}\text { Bottom } \\
\text { Ash }\end{array}$} & t2 & 48 & 1650 & 1085 & $\begin{array}{c}0.65 \\
8\end{array}$ & 460 & 157 & 0.341 \\
\hline & t3 & 64 & & 1520 & $\begin{array}{c}0.92 \\
1\end{array}$ & & 275 & 0.598 \\
\hline & t4 & 80 & & 1570 & $\begin{array}{c}0.95 \\
2\end{array}$ & & 214 & 0.465 \\
\hline & t5 & 96 & & 1330 & $\begin{array}{c}0.80 \\
6\end{array}$ & & 240 & 0.522 \\
\hline & t6 & 112 & & 1650 & $\begin{array}{c}1,00 \\
0\end{array}$ & & 234 & 0.509 \\
\hline & $\mathrm{t} 1$ & 29 & & 50 & $\begin{array}{c}0.03 \\
0\end{array}$ & & 189 & 0.411 \\
\hline \multirow[t]{6}{*}{ Fly Ash } & t2 & 45 & 1650 & 590 & $\begin{array}{c}0.35 \\
8\end{array}$ & 460 & 77 & 0.167 \\
\hline & t3 & 61 & & 1730 & $\begin{array}{c}1.04 \\
8\end{array}$ & & 176 & 0.383 \\
\hline & t4 & 77 & & 1830 & $\begin{array}{c}1.10 \\
9\end{array}$ & & 211 & 0.459 \\
\hline & t5 & 93 & & 1500 & $\begin{array}{c}0.90 \\
9\end{array}$ & & 285 & 0.620 \\
\hline & t6 & 109 & & 2150 & $\begin{array}{c}1,30 \\
3\end{array}$ & & 190 & 0.413 \\
\hline & $\mathrm{t} 1$ & 39 & & 760 & $\begin{array}{c}0.46 \\
1\end{array}$ & & 171 & 0.372 \\
\hline \multirow[t]{5}{*}{$\begin{array}{c}\text { Ash and Fly } \\
\text { Ash }\end{array}$} & t2 & 55 & 1650 & 1800 & $\begin{array}{c}1.09 \\
1\end{array}$ & 460 & 287 & 0.624 \\
\hline & t3 & 71 & & 2160 & $\begin{array}{c}1.30 \\
9\end{array}$ & & 193 & 0.420 \\
\hline & t4 & 87 & & 2580 & $\begin{array}{c}1.56 \\
4\end{array}$ & & 257 & 0.559 \\
\hline & t5 & 103 & & 2270 & $\begin{array}{c}1.37 \\
6\end{array}$ & & 216 & 0.470 \\
\hline & t6 & 119 & & 2510 & $\begin{array}{c}1.52 \\
1\end{array}$ & & 245 & 0.533 \\
\hline
\end{tabular}

The contact time of the solution with the adsorbent in the column was different even though the initial flow rate was set the same, namely $20 \mathrm{ml} / \mathrm{min}$. The longest contact time is when the column is stratified with bottom ash and fly ash media of 39 minutes, followed by bottom ash column of 32 minutes and fly ash of 29 minutes. The difference in contact time is influenced by the design of the column used, the adsorbent column still has leakage so that it affects the flow rate, the size of the adsorbent is very small so that the solution passed is difficult to find a gap to exit, and the influent flow that first enters the adsorption column is upflow. is still relatively smooth because the adsorbent condition is dry, The next influent flow will not be as smooth as the first influent flow because it is blocked by the pressure generated by the weight of the adsorbent in a wet state so that the time increases but the flow rate decreases. From the available data, it can be concluded that the removal of color and COD values is not only influenced by contact time but also by particle size, combustion process and adsorbent activation.

\subsection{Adsorption Capacity}

The adsorption capacity was used to determine the COD adsorption capacity with BA, FA and BF adsorbents. The adsorption capacity calculation was only carried out on the COD value, because the COD value already described the overall organic and inorganic materials contained in the artificial tea liquid waste.

Figure 5 shows the highest COD adsorption capacity possessed by adsorbent BF of 8.42 $\mathrm{mg} / \mathrm{g}$, followed by FA of $7.53 \mathrm{mg} / \mathrm{g}$, and the lowest COD adsorption capacity of BA adsorbent of $7.37 \mathrm{mg} / \mathrm{g}$. If viewed from the results of iodine adsorption, the value of FA adsorption capacity is 
higher than the value of BA adsorption, so the adsorption capacity value in Figure 4.14 is directly proportional to the result of iodine adsorption, while the BF capacity value which is higher than BA and FA is due to consisting of two different ash in one column, so that the molecules contained in the tea solution, both large and small can be adsorbed. FA has more micropores while BA does not have too many micropores, so the compoundsLarge compounds that are not adsorbed by FA can then be adsorbed by BA, using two or more adsorbents in one column will allow the compounds contained in tea waste to be more adsorbed.

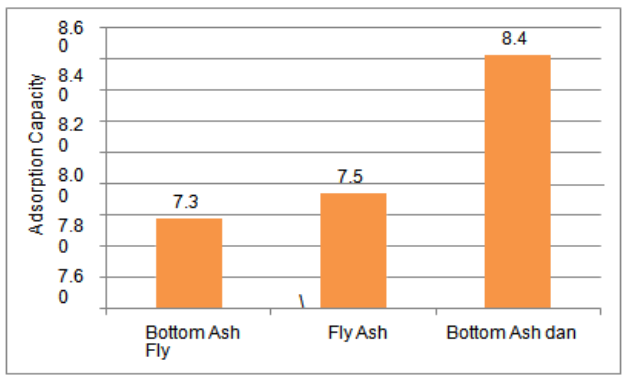

Figure 5. COD Adsorption Capacity of Each Adsorption Column

\section{CONCLUSION}

The water content obtained from the test results of the characteristics of the adsorbent, the FA water content before activation was higher than that of BA by $0.6 \%$ and $0.21 \%$, while after activation, BA was higher than FA by $0.34 \%$ and $0.09 \%$.

The ash content obtained from the test results of the characteristics of the adsorbent, FA ash content is higher than BA both after activation and before activation. The ash content of BA before activation was $0.035 \%$ and after activation was $0.069 \%$ and FA water before activation was $0.214 \%$ and after activation was $0.285 \%$.

lodine adsorption capacity of $\mathrm{FA}$ and $\mathrm{BA}$ adsorbents activated by $\mathrm{HCl}$ where $\mathrm{FA}$ has a higher adsorption capacity than BA, namely: $50.76 \mathrm{~m} / \mathrm{g}$ and $25.38 \mathrm{mg} / \mathrm{g}$.

The highest color removal efficiency was obtained by using an adsorption column with an adsorbent FA peda t1 of $96.96 \%$ then followed by an adsorption column of BF at $t 1$ of $53.93 \%$ and $\mathrm{BA}$ at $\mathrm{t} 1$ of $53.03 \%$. The highest COD removal efficiency was using a column with FA adsorbent at $\mathrm{t} 2$ of $83.26 \%$ followed by BA adsorption column at $\mathrm{t} 1$ of $71.08 \%$ and $\mathrm{BF}$ at $\mathrm{t} 1 \mathrm{of} 62.82 \%$.

The highest COD adsorption capacity was obtained using an adsorption column with adsorbent BF of $8.42 \mathrm{mg} / \mathrm{g}$, followed by FA of $7.53 \mathrm{mg} / \mathrm{g}$, and BA of $7.37 \mathrm{mg} / \mathrm{g}$.

\section{REFERENCES}

Abdulbari, A. Ahmad.,dkk. 2006. Basic Dye Removal from Synthetic Wastewater by Adsorption on Palm Ash. University Science Malaysia; Malaysia.

Ahmad, Mohd. Rafatullah., Arniza Ghazali., Othman Sulaiman dan Rokiah Hashim., 2011. Oil Palm BiomassBased Adsorbents For The Removal Of Water Pollutants AReview. Universiti Sains Malaysia; Penang.

Akbar, M. I., 2011. Pemanfaatan Arang Aktif Cangkang Kelapa Sawit Sebagai Adsorben Zat Warna pada Biodiesel. Skripsi Departemen IImu Kimia Fakultas Matematika dan IImu Pengetahuan Alam Institut Pertanian Bogor. Dipublikasi.

Altwai, Nurdeen M., Megat A. Megat Johari, Syed F. Saiyid Hashim., 2011. Influence of Calcination Temperature on Characteristics and Pozzolanic Activity of Palm Oil Waste Ash. Australian Journal of Basic and Applied Sciences, 5 (11). Halaman: 1010-1018.

AL-,Aoh H. A., M. JamilMaah., A.A.Ahmad., M. Radzi.2012. Isotherm and Kinetic Studies of 4-nitrophenol Adsorption by NaOH-Modified Palm Oil Fuel Ash.Journal of Purity, Utility Reaction and Environment 104120.

Anjani, Dwi., 2015. Pembuatan Silika Gel Menggunakan Abu Kerak Boiler PT. Sriwijaya Palm Oil Indonesia Terhadap Pengaruh Konsentrasi $\mathrm{Na}_{2} \mathrm{CO}_{3}$ Sebagai Pelarut. Skripsi Politeknik Negeri; Sriwijaya. 
Asyri, Fadhilla., Kartini Noor Hafni., dan A. Haris Simamora., 2015. Pengaruh Limbah Abu Pembakaran Biomassa Kelapa Sawit Terhadap Sifat-Sifat Fisika dan Mekanik High Impact Polystyrene. jurnal Teknik Kimia USU.

Abbas,Muhammad., Ahmad Zaini., Tee Yee Cher, Muaz Zakaria, Mohd. Johari Kamaruddin, Siti Hamidah Mohd. Setapar \& Mohd. Azizi Che Yunus.,

2016. Palm oil mill effluent sludge ash as adsorbent for methylene blue dye removal.Universiti Teknologi Malaysia; Penang.

Budiono, A., Suhartana, Gunawan., 2006. Pengaruh Aktivasi Arang Tempurung Kelapa dengan Asam Sulfat dan Asam Fosfat untuk Adsorpsi Fenol, Jurnal Kimia; Universitas Diponegoro.

Balittri, J. T.,2013. Kandungan Senyawa Kimia Pada Daun The (Cmellia Sinensis). Warta penelitian dan pengembangan tanaman industri.

Clair N. S., Perry, L. M., dan Gene, F. P., 2003. Chemistry for Environmental Engineering and Science. 5th edition. McGraw-Hill; New York.

Fadli, A., Komalasari, Roza, L., dan Maria, E., 2002. Penjerapan Fenol dengan Tandan Kosong Sawit (TKS) sebagai Adsorben. Prosiding Seminar Nasional Fundamental dan Aplikasi Teknik Kimia;Surabaya.

Febijanto, Irhan., 2010. Pemanfaatan Potensi Gas Metana di Pabrik Kelapa Sawit Sei Silau,PTPN 3, Sumatera Utara. J. Tek. Ling. Hal. 459- 474.

Farandia R. Y., Monita Olivia., Lita Darmayanti., 2015. Kinerja Beton High Volume POFA. Jurnal Program Studi Teknik Sipil Fakultas Teknik Universitas Riau; Pekanbaru.

Hadiwidodo, Mochtar., 2008. Penggunaan Abu Sekam Padi Sebagai Adsorben Dalam Pengolahan Air Limbah Yang Mengandung Logam Cu. Halaman :55-63.

Herlandien, Y. L., 2013, Pemanfaatan Arang Aktif sebagai Adsorban Logam Berat dalam Air Lindi di TPA Pakusari Jember. Skripsi Fakultas Matematika dan IImu Pengetahuan Alam; Universitas Jember.

Hudaya, Tedi., dan Wiratama G. P., 2016. Perancangan Kolom Adsorpsi Karbon Aktif untuk Pengolahan Limbah Kromium Heksavalen. Laporan Hibah Monopoli.Universitas Katolik Parahyangan. Bandung.

Idrus, R., Lapanporo, B, P., Putra, Y, S, 2013, Pengaruh Suhu Aktifasi Terhadap Kualitas Karbon Aktif BErbahan Dasar Tempurung Kelapa. Prisma Fisika. Halaman 50-51.

Irawan, Candra., Basri Dahlan.,Nawang Retno., 2015.Pengaruh Massa Adsorben, Lama Kontak Dan Aktivasi Adsorben Menggunakan HCl Terhadap Efektivitas Penurunan Logam Berat (Fe)Dengan Menggunakan Abu Layang Sebagai Adsorben. Jurnal Teknologi Terpadu. Hal 1-12.

Imla, Syafiqah., Hafizuddin Wan Yussof., Abdul Aziz Mohd Azoddein., Shivananda Chandraseagar., dan Faizal Wan Ishak., 2017. A Factorial Analysis Study on Removal of Mercury by Palm Oil Fuel Ash Adsorbent. Jurnal Faculty of Chemical Engineering \& Natural Resources, Universiti Malaysia Pahang. Halaman: 1-6.

K. Maghanga, F. K. Segor, L. Etiégni \& J. Lusweti., 2009. Electrocoagulation Method for Colour Removal In Tea Effluent: A Case Study Of Chemomi Tea Factory In Rift Valley, Kenya. Chemical Society of Ethiopia. Halaman: 371- 381.

Jamilatun, Siti., Intan Dwi Isparulita., Elza Novita Putri., 2014. Karakteristik Arang Aktif Dari Tempurung Kelapa Dengan Pengaktivasi $\mathrm{H}_{2} \mathrm{SO}_{4}$ Variasi Suhu dan Waktu. Jurnal Fakultas Teknologi Industri, Universitas Ahmad Dahlan; Yogyakarta.

Jannah., Miftahul., 2015. Pembuatan Silika Gel Dari Abu Cangkang Kelapa Sawit dan Fiber Kelapa Sawit PT. SPOI dengan Pengaruh Temperatur Ekstraksi. Skripsi Politeknik Negeri Sriwijaya; Palembang.

Laos, Landiana Etni., dan Arkilaus Selan., 2016. Pemanfaatan Kulit Singkong Sebagai Bahan Baku Karbon Aktif. Jurnal IImu Pendidikan Fisiku; Nusa Tenggara Timur. Halaman 32-36

Laos, Landiana.,Etni Masturi., Ian Yulianti., 2016. Pengaruh Suhu Aktivasi Terhadap Daya Serap Karbon Aktif Kulit Kemiri. Halaman: 1-6.

Metcalf \& Eddy 1991. Wastewater Engineering Treatment, Disposal and Reuse. 3th Edition. MC. Graw- Hill. New York. America.

Mu'jizah, S., 2010, Pembuatan dan Karakterisasi karbon Aktif dari Biji Kelor (Moringa oleifera. Lamk) dengan $\mathrm{NaCl}$ sebagai Bahan Pengaktif. Skripsi Fakultas Sains dan Teknologi. Universitas Islam Negeri Maulana Malik Ibrahim; Malang.

Malakootian M., dan Fatehizadeh A., 2010. Color Removal From Water by Coagulation/Caustic Soda and Lime. Department of Environmental Health Engineering, School of Public Health, Kerman University of Medical Sciences, Kerman, Iran. Halaman: 1-6.

Muthawali, D. I., 2013. Analisa COD Dari Campuran Limbah Domestik dan Laboratorium di Balai Riset dan Standarisasi Industri Medan. Jurnal FMIPA Universitas Sumatera Utara. Halaman: 1-13.

M, Istifiarti., dan Alfan, P., 2016. Penurunan Ion Besi (Fe) dan Mangan (Mn) dalam Air dengan Serbuk Gergaji Kayu Kamper. Jurnal Teknik ITS. Halaman: 11- 16. 
Nur T., Shim,W.G., dan Loganatahan, P.,2014. Nitrate removal using purolite A520E Ion Exchange Resin Bed Column Adsorption Modeling. International journal of Enviromental and science technology. Halaman: 1311-1320.

Pari, G., 2004. Kajian struktur arang aktif dari serbuk gergaji kayu sebagai adsorbe emisi formaldehida kayu lapis. disertasi. Bogor: Sekolah Pascasarjana, Institut Pertanian Bogor.

Patisarana, Grata., dan Mulfi Hazwi., 2012.Optimalisasi Efisiensi Termis Boiler Menggunakan Serabut Dan Cangkang Sawit Sebagai Bahan Bakar Jurnal Dinamis. Halaman: 16-26.

Putranto. A., dan Stephanie A., 2014. Pemodelan Perpindahan Massa Adsorpsi Zat Warna Pada Florisil dan Silica Gel dngan Homogeneous and

Prianti, E., Malino, B, A., dan Lapanporo, B,P., 2015. Pemanfaatan Abu Kerak Boiler Hasil Pembakaran Limbah Kelapa Sawit Sebagai Pengganti Parsial Pasir pada Pembuatan Beton. Positron.

Ruthven, D. M., 1984. Principle of Adsorption \& Adsorption Process. John Wiley \& Sons : New York,124-141.

Reynolds, T. D. dan Paul, A. R., 1996. Unit Operations and Processes in Environmental Engineering. Edisi kedua. PWS Publishing Company; USA.

Reza, Muhammad., Rahmi Karolina., dan Johannes Tarigan., 2014. Pengaruh Limbah Abu Boiler Dan Fly Ash Sebagai Bahan Pengganti Semen Dalam Campuran Beton. Universitas Sumtera Utara; Medan.

Standar Nasional Indonesia (SNI). 1995. Arang Aktif Teknis SNI 06-3730-1995. Jakarta: Dewan Standardisasi Nasional.

Sentosa, L.,2005. Kinerja Laboratorium Campuran Hot Rolled Asphalt dengan Abu Sawit sebagai Filler. Simposium VIII Forum Studi Transportasi Antar- Perguruan Tinggi. (FSTPT). Palembang; Universitas Sriwijaya.

Said, Muhammad., Arie Wagi Prawati., dan Eldis Murenda., 2008.Aktifasi Zeolit Alam Sebagai Adsorbent Pada Adsorpsi Larutan lodium.Jurnal Teknik Kimia.

Suhendra, D., dan E. R. Gunawan.,2010. Pembuatan Arang Aktif Dari Batang Jagung Menggunakan Aktivator Asam Sulfat dan Penggunaannya Pada Penyerapan Ion Tembaga (II). Jurnal Universitas Mataram. Halaman: 22-26.

Setiaka,Juniawan., Dra Ita Ulfin, MSi., Nurul Widiastuti, Ph.D.,2011. Adsorpsi Ion Logam Cu(li) dalam Larutan Pada Abu Dasar Batubara Menggunakan Metode Kolom. Prosiding Skripsi Jurusan Kimia Fakultas Matematika dan Ilmu Pengetahuan Alam Institut Teknologi Sepuluh Nopember.

Siti, Jamilatun., Intan Dwi Isparulita., dan Elza Novita Putri., 2014. Karakteristik Arang Aktif Dari Tempurung Kelapa Dengan Pengaktivasl $\mathrm{H}_{2} \mathrm{SO}_{4}$ Variasi Suhu dan Waktu. Fakultas Teknologi Industri, niversitas Ahmad Dahlan. Yogyakarta.

Suparma, Latif Budi., Tunggul W., Panggabean., Sandra Mude., 2014. Potensi Penggunaan Limbah Kelapa Sawit Sebagai Agregat Pengisi Pada Campuran Hot Rolled Sheet-Base. Jurnal Transportasi. Halaman:87-96.

Simarmata., 2017. Pengaruh Penggunaan Bottom Ash Kelapa Sawit dengan Aktivasi Fisik Terhadap Prestasi Mesin dan Emisi Gas Buang Sepeda Motor Bensin 4-Langkah. Skripsi Fakultas Teknik Universitas Lampung Bandar Lampung.

Triawan, Deni Agus., Nesbah Nesbah., dan Dyah Fitriani., 2017. Crude Palm Oil's (CPO) Fly Ash As A LowCost Adsorben For Removal Of Methylen Blue (Mb) From Aqueous Solution.Jurnal Kimia Riset. Halaman 10-15.

Utama, Selvy., Hans Kristianto dan Arenst Andreas., 2016.Adsorpsi Ion Logam Kromium (Cr (Vi)) Menggunakan Karbon Aktif dari Bahan Baku Kulit Salak. Prosiding Seminar Nasional Teknik Kimia "Kejuangan".Bandung. Halaman: 1-16.

Webar, W bend. M., 1972, "Adsorption in heterogenes Aqua in Sistem ", Jaour AWWA.

Wibowo, Santiyo., Wasrin Syafii., \& Gustan Pari., 2009. Karakteristik Arang Aktif Tempurung Biji Nyamplung (Calophyllum Inophyllum Linn). Balai Penelitian Kehutanan Aek Nauli, Kampus Kehutanan Terpadu Aek Nauli Sumatera Utara. Halaman: 1-19

W, Kusnanto Mukti., 2012., Penentuan Konsentrasi Permanganat (KMnO4). jurnal Jurusan Fisika, FMIPA Universitas Sebelas Maret; Surakarta.

Yulika, Jeni., 2010. Penjerapan Zat Warna Reaktif Cibacron Red Menggunakan Adsorben Sekam Padi. Skripsi Departemen Kimia Fakultas Matematika Dan IImu Pengetahuan Alam Institut Pertanian; Bogor.

Yelvi., dan Mukhli., 2013. Evaluasi Kinerja Campuran Beton Aspal Lapis Aus (AC- WC) Memakai Limbah AbuCPO Sebagai Filler. Jurnal Rekayasa Sipil.

Zarina, Y.,A. M. MustafaAl Bakri1, H. Kamarudin1, I. Khairul Nizar and A. R. Rafiza., 2013. Review on the Various Ash From Palm Oil Waste as Geopolymer Material. Red, Adv, Master. Sci. 34; Universiti Malaysia Perlis (UniMAP). hal.37-43. 